\title{
Quantitative characteristics of the Feyrter (APUD) cells of the neonatal rabbit lung in normoxia and chronic hypoxia
}

\author{
A. HERNANDEZ-VASQUEZ, J. A. WILL, AND W. B. QUAY
}

From the Department of Veterinary Science, and Neuroendocrine Section, Waisman Center on Mental Retardation and Human Development, University of Wisconsin, Madison, Wisconsin 52706, USA

Hernandez-Vasquez, A., Will, J. A., and Quay, W. B. (1977). Thorax, 32, 449-456. Quantitative characteristics of the Feyrter (APUD) cells of the neonatal rabbit lung in normoxia and chronic hypoxia. Our studies show that the apparent number of Feyrter cells in the lung declines during the neonatal period in normoxic rabbits, and that in hypoxic animals a uniformly and significantly lower number of cells occurs as compared with the normoxic rabbits. There is some indication of degranulation of cells in the hypoxic groups. It is suggested that environmental and/or physiological factors associated with the start of extrauterine life, or lung development, may affect the apparent number and probable level of activity of these cells. These changes seem to be enhanced by hypoxia.

Mast cells are scarce, and Feyrter cells are relatively more numerous along the airways. These cell types could possibly represent storage sites for 5-hydroxytryptamine, as suggested also by other investigators.

Intraepithelial nerve fibres in bronchi and bronchioles were found but they were not limited to innervations of Feyrter cells or related cell bodies.

Since Feyrter (1938) described the 'diffuse endocrinic epithelial organ' as composed of 'clear cells' present in some endodermally derived organs, such cells have been identified also in the epithelium of the airways of several mammals including man (Fröhlich, 1949; Feyrter, 1953; Bensch et al., 1965; Lauweryns and Peuskens, 1969; Cutz and Conen, 1972; Hage, 1972; Moosavi et al., 1973; Cutz et al., 1974; Lauweryns et al., 1974). These cells have been incorporated into the amineprecursor-uptake-decarboxylase (APUD) system proposed by Pearse (1969), and they are seen either as isolated cells or in groups. In both types of distribution the cytochemical and ultrastructural characteristics of the cells appear to be the same. Lauweryns and Cokelaere (1973) and Hage (1974) reported that the Feyrter or APUD cells of the lung form a storage and secretion site of 5hydroxytryptamine. These endocrine-like cells can be identified by their argyrophilic staining and formalin-induced fluorescence. On the basis of their histochemical and fine structural characteristics, the APUD cell type has been established and appears to be identical by both techniques. They are also said to be in contact with nerve fibres (Fröhlich, 1949; Bensch et al., 1965; Lauweryns and Peuskens, 1972; Cutz et al., 1974). Lauweryns and Cokelaere (1973) also suggested that these cells possibly contain and secrete related amines and peptides, which could influence the hypoxic pulmonary vasoconstrictor response. Depletion of their cytoplasmic dense cored vesicles by reserpine, or in response to hypoxia, was given as evidence for these suggestions.

Similar findings were reported by Moosavi et al. (1973), who found a decline in the number of Feyrter cells during the rat's neonatal period, using a semiquantitative method. The possible effect of lung growth on this calculation was not taken into account. These authors also tested the influence of acute hypoxia on the number of cells per centimetre of airways epithelium and found no significant difference between the control and test groups at 4 days of age. According to Lauweryns et al. (1974), the presence of 'neuroepithelial bodies' (for example, innervated APUD 
cells) in the fetal lung could "contribute to explanations of the active pulmonary vasoconstriction during fetal life, the rapid vasodilation upon aeration and even the pulmonary hypoperfusion during the idiopathic respiratory distress syndrome'. Even if the characteristics of these APUD cells had been defined, we still did not know whether or not there was a real difference in the estimated total number of cells among neonatal rabbits at different ages, as well as the effect of chronic hypoxia on those numbers. Therefore, to investigate the incidence of Feyrter cells in the epithelium of intrapulmonary airways in neonatal rabbits, and the variations in number during normoxia and chronic hypoxia, we counted the cells of 1-, 5-, and 10-day-old white New Zealand rabbits, in animals born at 260 metres above sea level, and in neonates born and maintained at a simulated altitude of $3100 \mathrm{~m}$ above sea level. We also wished to determine if a relationship exists between the numbers of APUD cells and mast cells in the lungs. A light microscopic survey for nerve fibres in the epithelium was carried out also.

\section{Material and methods}

Table 1 summarises the animal studies providing data in this report.

Table 1 Animal studies: litters/total no. (no. per litter)

\begin{tabular}{llll}
\hline Animals & Age & & \\
\cline { 2 - 4 } & 1 day & 5 days & 10 days \\
\hline Control & $2 / 6(3: 3)$ & $2 / 7(4: 3)$ & $2 / 8(4: 4)$ \\
Hypoxic & $1 / 4$ & $1 / 5$ & $1 / 4$ \\
\hline
\end{tabular}

Hypoxia was established by putting 1-year-old does at 15 days pregnancy into a chamber at a simulated altitude of $3105 \mathrm{~m}$ above sea level $\left(\mathrm{P}_{\mathrm{B}}=522 \mathrm{mmHg}\right)$. They were maintained at $23^{\circ} \mathrm{C}$, $50 \%$ relative humidity with an average of 23 hours of hypoxia per day before parturition and 23.5 hours per day after that.

Animals at 1 and 5 days after birth were killed by decapitation or sodium pentobarbital injection, whereas 10-day-old animals were killed by sodium pentobarbital injection. The hypoxic rabbits were killed 2-15 minutes after they had been removed from the hypobaric chamber. Bouin's fixative was instilled through the trachea at a constant pressure at $11.8,11.4$, and $11.2 \mathrm{~cm}$ of water for the 1-, 5and 10-day-old groups, until the lungs expanded completely in the closed chest, as suggested by Dunnill et al. (1972). Time of perfusion was the same in all groups. The lungs were removed and their volume was estimated by water displace- ment. They were then immersed in Bouin's fixative for 18-24 hours and a new volumetric estimation was made to assure that no changes in volume occurred during fixation. Each lobe of each lung was sectioned in two parts by making a saggital section in the midline so that in all groups the complete area of the section could fit on one slide for histological examination. We assumed the Feyrter cells to be randomly distributed and that 'a tissue section is a quantitatively representative two-dimensional sample of a threedimensional system of randomly distributed tissue structures' (Weibel, 1963). The blocks were cut serially at 7 microns; for staining of the sections we used the method of Grimelius (1968) using $0.06 \%$ silver nitrate as modified by Schesweisthal et al. (1975).

Several stains for identification of the APUD cells were used: the Fontana-Masson argentaffin reaction (Luna, 1968); Solcia's lead-haematoxylin stain (Solcia et al., 1971); and Holmes' argyrophilic technique (1943), which was also used for identification of nerve fibres. A systematic search for mast cells was performed using three animals per group; the sections were stained with Luna's stain for mast cells (Luna, 1968).

After the number of isolated cells and the number of groups of cells had been counted in each section, the images of the sections were projected on a piece of paper, the contours were outlined, and the drawings thus obtained cut so as to give an exact outline of the sections. The pieces of paper were weighed and the weights compared to that of a piece of paper of known dimensions in order to determine the equivalent size of the paper. The projected size was calibrated using a slide micrometer and the projected measurements were divided by the calibration factor obtained. The result of this division gave us the real area of the section. This area multiplied by the thickness of the section is the estimated volume of the section.

The number of cells per unit of lung volume was obtained by extrapolation of the number of cells counted per estimated volume of the sections to the number of cells that would be in the unit volume of the lungs assuming a direct proportion with the data obtained. An analysis of variance of the groups was carried out and differences among and between groups were determined following Duncan's procedure (Steel and Torrie, 1960).

\section{Results}

The argyrophilic cells were present in the epithelium of all the intrapulmonary airways, although 
they were more frequently seen in the small bronchi and respiratory bronchioles. No preferential site for any particular lobe seemed to occur. The groups of Feyrter cells were distributed in a similar manner.

The isolated cells were found to have different shapes, dimensions, and distribution in the epithelium. They were usually columnar and, on occasion, extremely narrow. Cytoplasmic projections were present in some cells, as in Fig. 1, where one of them could have reached the lumen of the airways. However, most of the single cells did not have such processes (Fig. 2).

Cells within groups did not generally have as narrow a cytoplasmic mass as did some of the isolated Feyrter cells. The number of cells per group varied from 2 to 20 with an average of 4 cells. In several groups of cells of the hypoxic animals, there was some indication of depletion of cytoplasmic content (Fig. 4). The Feyrter cells of the lungs stained neither with the FontanaMasson nor with Solcia's lead-haematoxylin technique. They did stain using Holmes' technique for argyrophilia and nerve fibres. Although a considerable search for mast cells was made in the lungs of the neonatal rabbits, only a few were found.

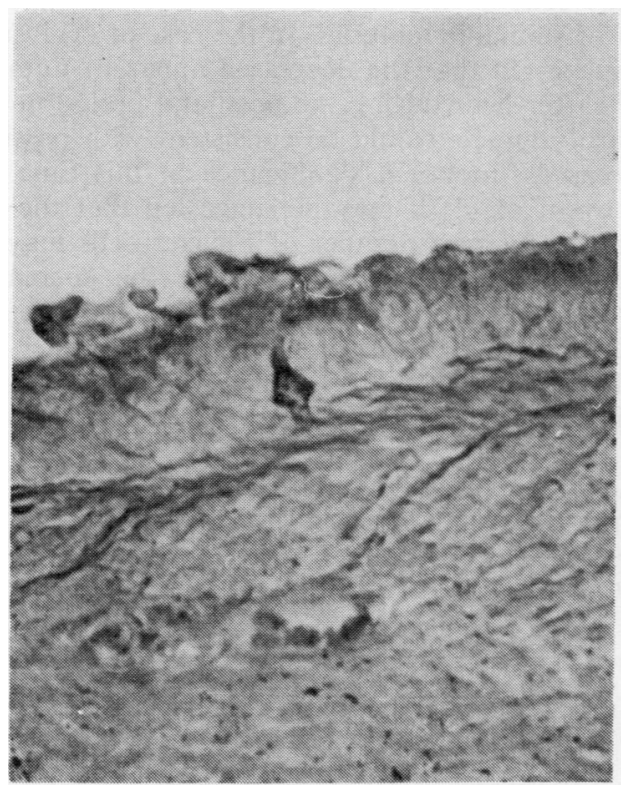

Fig. 1 Isolated Feyrter cell in the epithelium of a bronchus of a 10-day-old rabbit. Note the cytoplasmic processes and the 'neuron-like' anatomy of the cell. Modified Grimelius stain $(\times 1500)$.

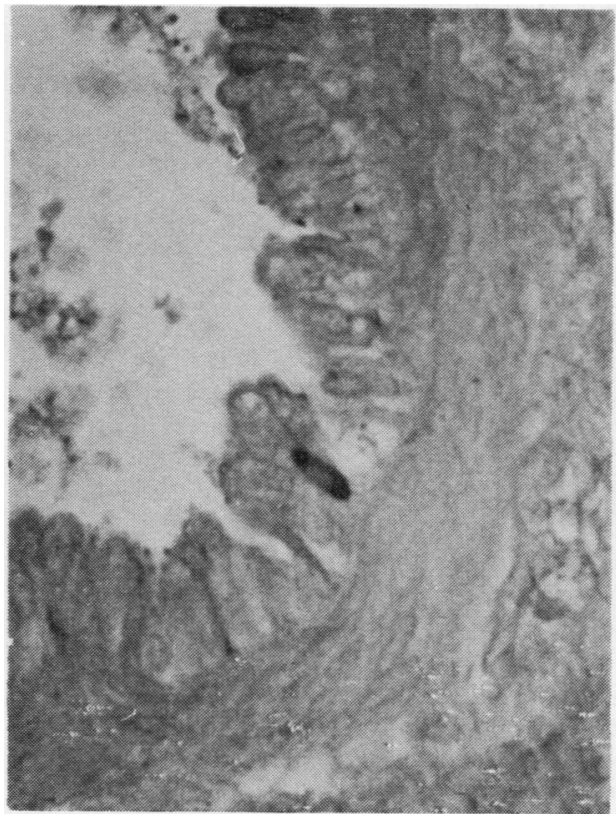

Fig. 2 Feyrter cell in a bronchiole of a 1-day-old rabbit. Note that the cell does not reach the lumen. Modified Grimelius stain $(\times 1500)$.

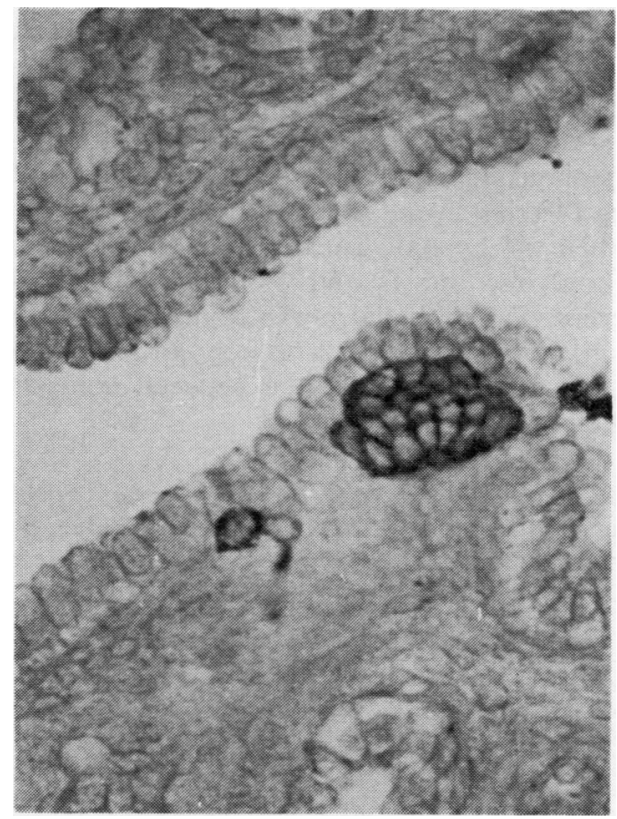

Fig. 3 Grouped Feyrter cells and an isolated Feyrter cell in a bronchiole. Note the processes attached to this single cell. Same animal as in Fig. 1 (X1500). 


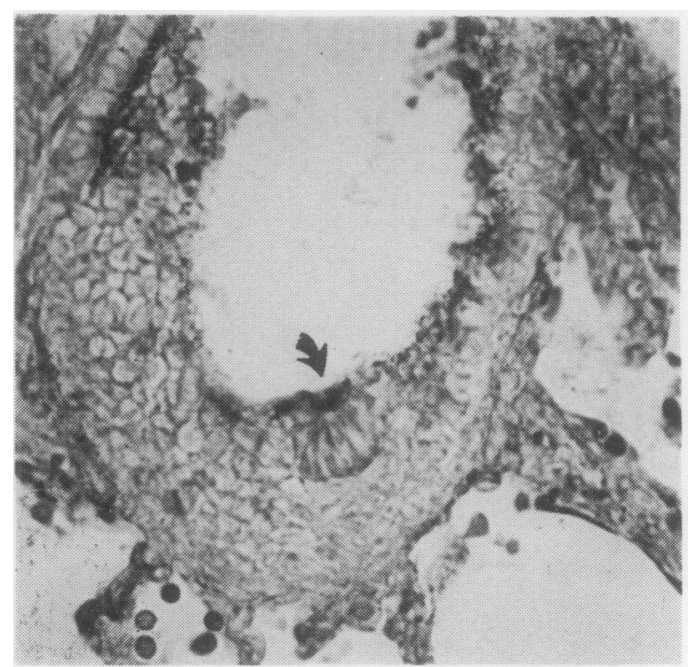

Fig. 4 A group of Feyrter cells in a bronchiole of a 1-day-old hypoxic rabbit. These cells appear to be depleted of their argyrophilic contents. Modified Grimelius stain $(\times 1500)$.

The quantitative results are summarised in Tables 2 and 3 and in Figs 5 and 6. From these figures, it is evident that the number of Feyrter cells per cubic millimetre in the lung declined during the neonatal period.

In the normoxic groups, 1-day-old animals were significantly different from all other groups and the 5-day-old group presented significant differences from the 10-day-old group. Among the hypoxic groups there were no significant differences (Tables 2 and 3).

When the hypoxic animals were compared with the controls, the 1 - and 5-day-old rabbits were different. Subepithelial nerve fibres can be identified in the walls of small bronchi and bronchioles and nerve fibres can be seen between non-APUD epithelial cells (Fig. 7).
Table 3 Number of isolated and groups of APUD cells per cubic millimetre of lung: summary of the Duncan's test: mean values arranged in ascending order, all groups considered

\begin{tabular}{|c|c|c|c|c|c|}
\hline \multicolumn{6}{|c|}{ Isolated cells } \\
\hline $\begin{array}{l}1 \text { day }_{\mathrm{H}} \\
0.03\end{array}$ & $\begin{array}{l}10 \text { days } \mathrm{H} \\
0 \cdot 10\end{array}$ & $\begin{array}{l}5 \text { days }_{\mathrm{H}} \\
0.16\end{array}$ & $\begin{array}{l}10 \text { days } \\
0 \cdot 18\end{array}$ & $\begin{array}{l}5 \text { days } \\
0.66\end{array}$ & $\begin{array}{l}1 \text { day } \\
1.78\end{array}$ \\
\hline \multicolumn{6}{|c|}{ Groups of cells } \\
\hline $\begin{array}{l}1 \text { day }_{\mathrm{H}} \\
0.09\end{array}$ & $\begin{array}{l}10 \text { days }_{H} \\
0 \cdot 26\end{array}$ & $\begin{array}{l}10 \text { days } \\
0 \cdot 26\end{array}$ & $\begin{array}{l}5 \text { days } \\
0.40\end{array}$ & $\begin{array}{l}5 \text { days } \\
1.08\end{array}$ & $\begin{array}{l}1 \text { day } \\
3.43\end{array}$ \\
\hline
\end{tabular}

Any 2 means not underscored by the same line are significantly different. Two means underscored by the same line are not significantly different. $5 \%$ Level. The subscript $\mathrm{H}$ indicates a hypoxic group.

\section{Discussion}

Our studies show that the number of Feyrter cells declines from 1 to 10 days of age in normoxic rabbits, whereas in the experimental group (chronic hypoxic) the number of cells is low at 1 day of age and no significant changes occur during the subsequent 9 days (Figs 5 and 6).

The changes in apparent number of Feyrter cells in early postnatal life shown by our results could have been induced possibly by respiration and/or hypoxia as a consequence of one or both of two kinds of changes: (1) changes in the actual number of differentiated or functional Feyrter cells, and/or (2) changes in the demonstrability of the cells on the basis of their cytoplasmic content of stainable material. In the case of (1) it may be suggested that the decreased apparent number of Feyrter cells during the postnatal period in the control animals would be consistent with possible decreased functional significance at this time. In the event of (2) it may be suggested that the decreased apparent number of Feyrter cells may be due in part to decreased storage (the decreased storage may then imply an increased secretory activity) of cytoplasmic product(s). While the probable importance of changes in the neonatal period is clear, the functional directions or impli-

Table 2 Number of isolated and groups of APUD cells per cubic millimetre in the lung of the rabbit: mean values in the groups of neonatal animals. Control $\mathrm{v}$ Hypoxic (comparisons between groups of the same age)

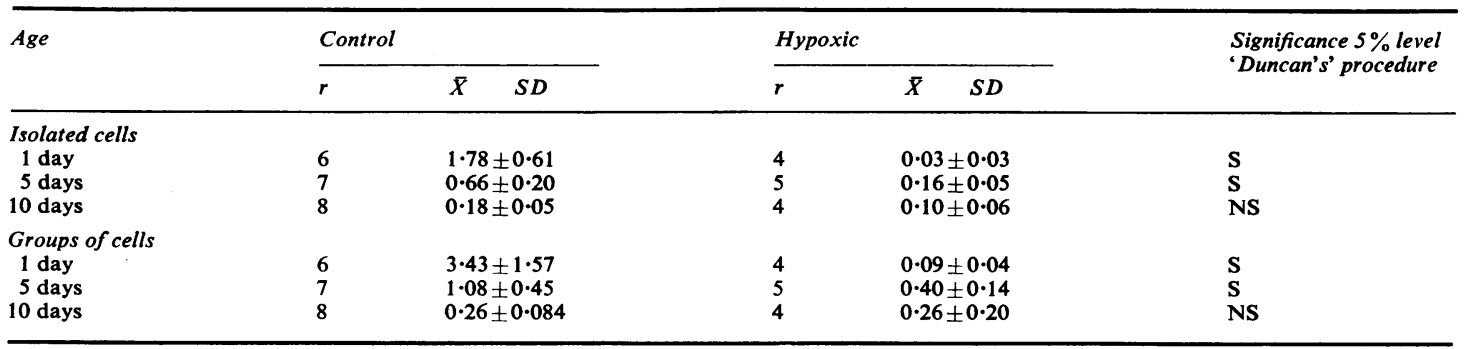

$\mathbf{S D}=$ standard deviation. $\mathbf{S}=$ significantly different. $\mathrm{r}=$ number of animals in each group. $\mathrm{NS}=$ not significantly different . 


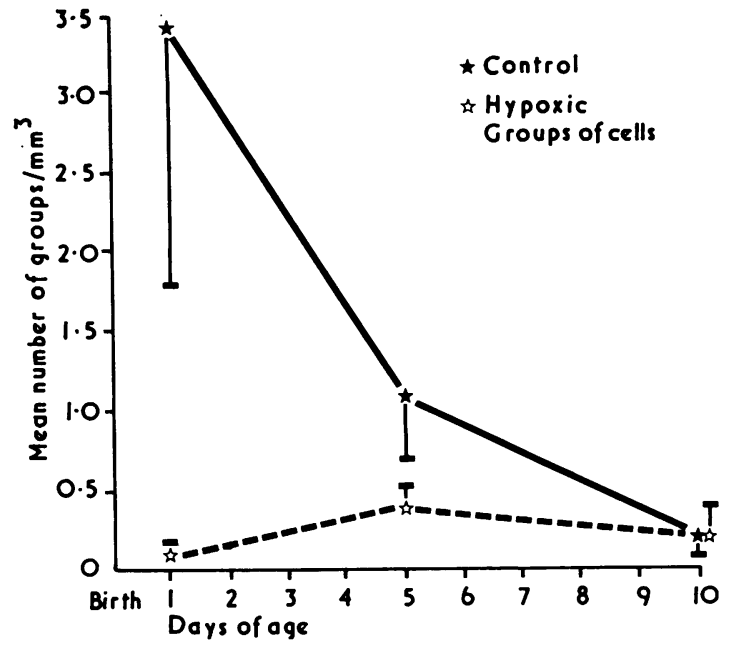

Fig. 5 Relationships between groups of Feyrter cells and time after birth in control and hypoxic rabbits.

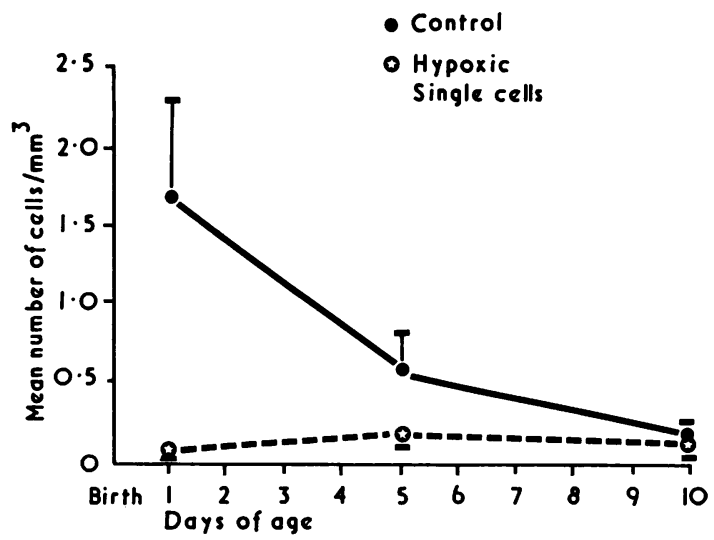

Fig. 6 Relationships between single Feyrter cells and time after birth in control and hypoxic rabbits.

cations of those changes are not. Nevertheless, it may be suggested that some environmental or physiological factors associated with the start of extrauterine life and lung maturation affect the apparent number and probable level of activity of these cells; these changes seem to be enhanced by alveolar hypoxia. When we examined the lungs of hypoxic animals 1 day after birth, apart from the quantitative differences between this group and the corresponding control animals, the groups of cells appeared to be depleted of their contents in several instances in the hypoxic group; this observation was not characteristic of the control animals. The same depletion was seen in the 5day-old hypoxic animals, but to a considerably

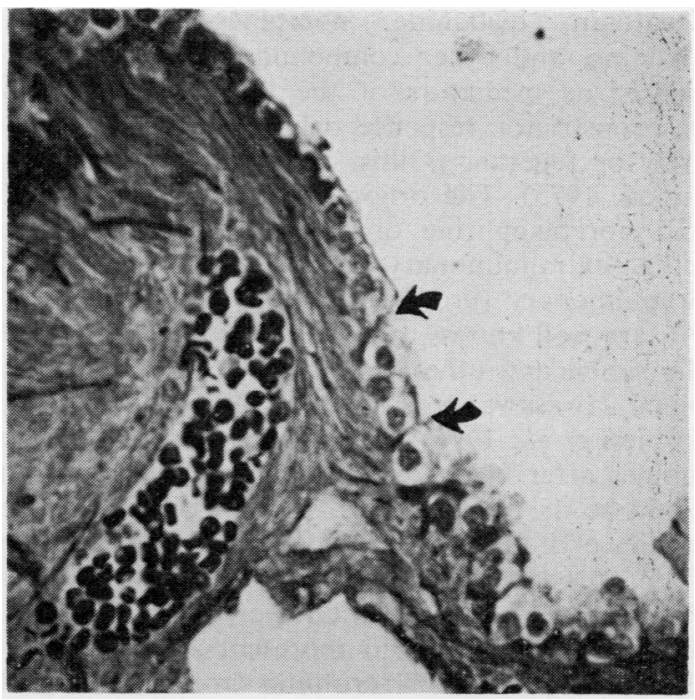

Fig. 7 Intraepithelial nerve fibres (arrows) between non-Feyrter cells in a small bronchus of a 1-day-old rabbit. Note subepithelial nerve fibres. Holmes' stain $(\times 1500)$.

lesser degree than in the 1-day-old hypoxic group. Since we have only light microscopic observations at this time more detailed aspects of interpretations of these results will have to await supporting ultrastructural, biochemical, and physiological observations.

Various effects of hypoxia on pulmonary cells have been reported independently by other workers, which may indicate a generalised stimulus: (a) depletion of intracytoplasmic dense core vesicles of the Feyrter cells in rats and rabbits during acute hypoxia (Lauweryns and Cokelaere, 1973; Moosavi et al., 1973). This agrees with our present findings of a decrease in the estimated number of Feyrter cells and possibly degranulation during chronic hypoxia; $(b)$ degranulation of mast cells in rats and guinea-pigs (Haas and Bergofsky, 1972); (c) inhibition of phagocytic activity of the alveolar macrophages in rabbits subjected to chronic hypoxia (Durnova et al., 1975); (d) there is also evidence that hypoxia causes a reduction in the number of circulating platelets in man (Gray et al., 1975), mice (Birks et al., 1975), cattle (Genton et al., 1970), and rats (De Gabriele and Penington, 1967), although platelets may not be essential for the pulmonary vascular pressure response to hypoxia (Weir et al., 1976).

Substances contained in all these cells are released when alveolar hypoxia has been provoked. 
Serotonin, histamine, norepinephrine, prostaglandins, and other compounds have been considered as mediators of the hypoxic pulmonary vasoconstrictor response, which might act separately or together (Gillis, 1973; Said et al., 1974; Junod, 1975). The origin of substances like 5HT and norepinephrine or their precursors can be either extrapulmonary (eg, coming in the blood) or pulmonary (produced by the lung). 5HT and NE are well known to be extracted by the lung of the rabbit and other species from the pulmonary blood (Iwasawa et al., 1973; Will et al., 1975; Cronau et al., 1976). One site for storage of these amines after being removed from the circulation could be the Feyrter cells, since, according to the studies of Lauweryns and Cokelaere, they contain 5HT, probably among other biogenic amines (Lauweryns et al., 1973; Lauweryns et al., 1974). The Feyrter cells could represent a site for synthesis and release of serotonin from the lung of the rabbit which may be liberated under different conditions, including hypoxia.

It is to be noted that in the lung of the guineapig where mast cells are abundant, the Feyrter cells of the lung are either scarce or absent (Hage, 1974; Hernandez et al., unpublished observations). We did not find significant numbers of mast cells in the lungs of the normoxic neonatal animals used. Rabbits and humans are two species with a larger number of Feyrter cells in the airways, as compared to lambs and armadillos (Cutz et al., 1975).

The idea of a possible storage role of the Feyrter cells of the lung was also proposed by Lauweryns and Cokelaere (1973), Hage (1974), and Winckler (1976). It is also of interest to note that in pulmonary hypertension in man, the removal of 5HT and norepinephrine from the pulmonary circulation is quantitatively enhanced (Gillis et al., 1972, 1974). It is possible that this change is related to the diminished number of identifiable cells due to hypoxia reported in this paper.

We have seen that the bronchial and bronchiolar epithelium is innervated in neonatal animals, but not only in the selective way described by other investigators (Lauweryns and Cokelaere, 1973; Cutz et al., 1974); (eg, only the Feyrter cells were reported to be innervated, forming the so-called 'neuroepithelial bodies'). Similar observations are available from several species. There are unmyelinated epithelial axons in the trachea of humans (Rhodin, 1966), in the bronchi of rabbits and guinea-pigs (Fillenz and Woods, 1970), in the tracheobronchial tree of the cat (Hung, 1976) and rat (Jeffery and Reid, 1973), and also in the bronchi of birds (King et al., 1974) and mice (Hung and Loosli, 1974). The physiological significance of these nerve fibres remains obscure. An electron microscopical differentiation of the various types of fibres in the airways would be desirable as a contribution to the understanding of their function.

We are grateful to Mrs. Janice Lokken and Mrs. Barbara Freedman for technical assistance. We are also indebted to Mr. Charles A. Baum for help in operating the altitude chamber in the Biotron, University of Wisconsin, Madison. This research was supported by the College of Agricultural and Life Sciences, University of Wisconsin-Madison and a grant from the Council for Tobacco Research (1036).

\section{References}

Bensch, K. G., Gordon, G. B., and Miller, L. R. के (1965). Studies on the bronchial counterpart of the Kultschitzky (argentaffin) cell and innervation of bronchial glands. Journal of Ultrastructure Research, 12, 668-686.

Birks, J. W., Klassen, L. W., and Gurney, C. W. (1975). Hypoxia-induced thrombocytopenia in mice. Journal of Laboratory and Clinical Medicine, 86, 230-238.

Cronau, L. H., Kerstein, M. D., Mandel, S., and Gillis, C. N. (1976). 5-Hydroxytryptamine extraction by the lung. Surgery, Gynecology, and Obstetrics, 143, 51-55.

Cutz, E., Chan, W., Wong, V., and Conen, P. E. (1974). Endocrine cells in rat fetal lungs. Ultrastructural and histochemical study. Laboratory Investigation, 30, 458-464.

Cutz, E., Chan, W., Wong, V., and Conen, P. E. (1975). Ultrastructure and fluorescence histochemistry of endocrine (APUD-type) cells in tracheal mucosa of human and various animal species. Cell and Tissue Research, 158, 425-437.

Cutz, E., and Conen, P. E. (1972). Endocrine-like cells in human fetal lungs: an electron microscopic study. Anatomical Record, 173, 115-122.

De Gabriele, G., and Penington, D. G. (1967). Physiology of the regulation of platelet production. British Journal of Haematology, 13, 202-209.

Dunnill, M. S., Fletcher, C. M., Cumming, G., Heath, D. A., Heppleston, A. G., Lamb, D., Leopold, J. G., and Wagner, J. C. (1972). In Report by Panel on Pathology of the Medical Research Council Committee on Research into Chronic Bronchitis. Quantitative Assessment of Chronic Non-Specific Lung Disease at Necropsy. Distributed by Lung Program, National Heart and Lung Institute, Bethesda, Maryland.

Durnova, G. N., Kaplanskii, A. S., and Portugalov, V. V. (1975). Effect of hypoxia on function and metabolism of the alveolar macrophage. Byulleten, 
Eksperimental' noi Biologii $i$ Meditsiny, 79, 3, 113115.

Feyrter, F. (1938). Über diffuse endokrine epitheliale Organe. Barth, Leipsig. Cited by Bensch, K. G. Gordon, G. B., and Miller, L. R. (1965). Studies on the bronchial counterpart of the Kultschitzky (argentaffin) cell and innervation of bronchial glands. Journal of Ultrastructure Research, 12, 668-686.

Feyrter, F. (1953). Ueber die peripheren endokrinen (parakrinen) Druesen des Menschen. W. Maudrich, Wien-Dusseldorf.

Fillenz, M., and Woods, R. I. (1970). Sensory innervation of the airways. In Breathing. HeringBreuer Centenary Symposium, edited by R. Porter, pp. 101-109. Churchill, London.

Frölich, F. (1949). Die "helle Zelle" der Bronchialschleimhaut und ihre Beziehungen zum Problem der Chemoreceptoren. Frankfurter Pathologie, 60, 517 559.

Genton, E., Ross, A. M., Takeda, Y. A., and Vogel, J. H. K. (1970). Alterations in blood coagulation at high altitude. Advances in Cardiology, 5, 32-40.

Gillis, C. N. (1973). Metabolism of vasoactive hormones by lung. Anaesthesiology, 39, 626-632.

Gillis, C. N., Cronau, L. H., Greene, N. M., and Hammond, G. L. (1974). Removal of 5-hydroxytryptamine and norepinephrine from the pulmonary vascular space of man: influence of cardiopulmonary bypass and pulmonary arterial pressure on these processes. Surgery, 76, 608-616.

Gillis, C. N., Greene, N. M., Cronau, L. H., and Hammond, G. L. (1972). Pulmonary extraction of 5hydroxytryptamine and norepinephrine before and after cardiopulmonary bypass in man. Circulation Research, 30, 666-674.

Gray, G. W., Bryan, A. C., Freedman, M. H., Houston, C. S., Lewis, W. F., McFadden, D. M., and Newell, G. (1975). Effect of altitude exposure on platelets. Journal of Applied Physiology, 39, 648-651.

Grimelius, L. (1968). A silver nitrate stain for $\alpha 2$ cells in human pancreatic islets. Acta Societatis Medicorum Upsaliensis, 73, 243-270.

Haas, F., and Bergofsky, E. H. (1972). Role of the mast cell in the pulmonary pressor response to hypoxia. Journal of Clinical Investigation, 51, 3154-3162.

Hage, E. (1972). Endocrine cells in the bronchial mucosa of human foetuses. Acta Pathologica et Microbiologica Scandinavica, 80A, 225-234.

Hage, E. (1974). Histochemistry and fine structure of endocrine cells in foetal lungs of the rabbit, mouse and guinea pig. Cell and Tissue Research, 149, 513524.

Holmes, W. (1943). Silver staining of nerve axons in paraffin sections. Anatomical Record, 86, 157-187.

Hung, K. S. (1976). Fine structure of tracheo-bronchial epithelial nerves of the cat. Anatomical Record, 185, 85-87.

Hung, K. S., and Loosli, C. G. (1974). Bronchiolar neuro-epithelial bodies in the neonatal mouse lungs. American Journal of Anatomy, 140, 191-199.

Iwasawa, Y., Gillis, C. N., and Aghajanian, G. (1973). Hypothermic inhibition of five-hydroxytryptamine and norepinephrine uptake by lung: cellular location of amines after uptake. Journal of Pharmacology and Experimental Therapeutics, 186, 498507.

Jeffery, P., and Reid, L. (1973). Intra-epithelial nerves in normal rat airways: a quantitative electron microscopic study. Journal of A natomy, 114, 35-45.

Junod, A. F. (1975). Metabolism, production, and release of hormones and mediators in the lung. American Review of Respiratory Disease, 112, 93108.

King, A. S.. McLelland, J., Cook, R. D., King, D. Z., and Walsh, C. (1974). The ultrastructure of afferent nerve endings of the avian lung. Respiration Physiology, 22, 21-40.

Lauweryns, J. M., and Cokelaere, M. (1973). Hypoxiasensitive neuroepithelial bodies. Intrapulmonary secretory neuroreceptors, modulated by the CNS. Zeitschrift für Zellforschung und mikroskopische Anatomie, 145, 521-540.

Lauweryns, J. M., Cokeleare, M., Theunynck, P., (1973). Serotonin producing neuroepithelial bodies in rabbit respiratory mucosa. Science, 180, 410413.

Lauweryns, J. M., Cokeleare, M., Theunynck, P., and Deleersynder, M. (1974). Neuroepithelial bodies in mammalian respiratory mucosa: light optical, histochemical and ultrastructural studies. Chest, $65,22 \mathrm{~S}-29 \mathrm{~S}$.

Lauweryns, J. M., and Peuskens, J. C. (1969). Argyrophil (kinin and amine producing?) cells in human infant airway epithelium. Life Sciences, 8, 577-585.

Lauweryns, J. M., and Peuskens, J. C. (1972). Neuroepithelial bodies (neuroreceptor or secretory organs?) in human infant bronchial and bronchiolar epithelium. Anatomical Record, 172, 471-481.

Luna, L. G. (1968). Methods for cytoplasmic granules. In Manual of Histologic Staining Methods of the Armed Forces Institute of Pathology, 3rd edition, edited by L. G. Luna, pp. 104, 114. McGraw-Hill, New York.

Moosavi, H., Smith, P., and Heath, D. (1973). The Feyrter cell in hypoxia. Thorax, 28, 729-741.

Pearse, A. G. E. (1969). The cytochemistry and ultrastructure of polypeptide hormone-producing cells of the APUD series and the embryologic, physiologic, and pathologic implications of the concept. Journal of Histochemistry and Cytochemistry, 17, 303-313.

Rhodin, J. A. G. (1966). Ultrastructure and function of the human tracheal mucosa. American Review of Respiratory Disease, 93 (Suppl. March), 1-15).

Said, S. I., Yoshida, T., Kitamura, S., and Vreim, C. (1974). Pulmonary alveolar hypoxia: release of prostaglandins and other humoral mediators. Science, 185, 1181-1183. 
Schweisthal, M. R., Frost, C. C., and Brinn, J. E. (1975). Stains for A, B and D cells in fetal rat islets. Stain Technology, 50 (3), 161-170.

Solcia, E., Capella, E., and Vassallo, G. (1971). On the staining of the gastrin cell (Letter). Gastroenterology, 61, 794.

Steel, R. G. D., and Torrie, J. H. (1960). Analysis of variance. I. The one-way classification. In Principles and Procedures of Statistics with Special Reference to the Biological Sciences, p. 112. McGraw-Hill, New York.

Weibel, E. R. (1963). Principles and methods of morphometry. In Morphometry of the Human Lung, p. 13. Springer, Berlin. Academic Press, New York.

Weir, E. K., Seavy, J., Mlczoch, J., Genton, E., and
Reeves, J. T. (1976). Platelets are not essential for the pulmonary vascular response to hypoxia. Journal of Laboratory and Clinical Medicine, 88, 412-416.

Will, J. A., Katomski, P., Buss, D. D., and Will, D. H. (1975). Norepinephrine uptake in the lung. A relationship to pulmonary vascular reactivity? (Abstract). Physiologist, 18, 451.

Winckler, J. (1976). Biogene Amine in Polypeptidhormon-bildenden Zellen. Die APUD-Zellen (Pearse). Klinische Wochenschrift, 54, 49-58.

Requests for reprints to: Professor James A. Will, Department of Veterinary Science, University of Wisconsin, Madison, Wisconsin 53706, USA. 